\title{
Nutrient Contents of Major Food Plants Eaten by Cattle in the South Texas Plains
}

\author{
C.L. GONZALEZ AND J.H. EVERITT
}

\section{Abstract}

From May 1975 to November 1977, whole plant samples of 6 native and 2 introduced grass species, and top pads of 1 browse (pricklypear cactus) species were collected monthly and analyzed for crude protein (CP), P, Na, K, Ca, Mg contents, and digestible energy (DE) to determine their nutritive value as range forage. Digestible energy, CP and P levels, were deficient, especially in winter and early spring for lactating cows but were near to marginal for dry cows. All other elements, except $\mathrm{Na}$, were present at amounts adequate to meet all cattle requirements. Sodium levels were low, but probably would not pose a problem if free choice salt was provided. Any deficiencies may be alleviated by cattle selection of higher quality plants, such as forbs and short-lived annual grasses. Pricklypear cactus had low levels of $C P, P$, and $N a$ but high levels of estimated DE $(2900 \mathrm{~K} \mathrm{cal} / \mathrm{kg})$; however, pricklypear cactus is high in soluble ash (20\%) and if expressed as in vitro digestible organic matter, DE is considerably reduced. These data suggest that protein should be supplemented to lactating cows in winter and early spring while $P$ probably should be supplemented all year.

The 7 million hectares of rangeland in the South Texas Plains make up one of the largest native range areas for beef production (cow-calf operation) in Texas (Gould 1975). Ranch enterprises are vital to the area's economy; however, it is increasingly difficult to make a profit from range operations. The key for ranchers to remain in business is to increase their production of high quality forage.

Little research has been conducted on important food plants eaten by cattle on South Texas rangelands (Davis 1952). Cattle production from rangelands depends on rainfall distribution, forage quality, stocking rates, and other management practices. Improving nutritive value of major cattle foods on native range is essential for increasing cattle production; however, range forage nutrition information is limited.

This investigation was conducted to determine the nutritive value of major range forage species eaten by cattle grazing on a red sandy loam range site. This study is part of another study, conducted by Everitt et al. (1981), that gives details on botanical composition of cattle diets and range forage availability from September 1976 to November 1977.

\section{Materials and Methods}

The study was conducted on a red sandy loam site on the Tijerina Ranch located in northwestern Hidalgo County, Texas, from May 1975 to November 1977. Details of this site were described by Everitt et al. (1981).

Six native and 2 introduced grass species, and 1 browse species

\footnotetext{
Authors are range scientists, respectively, U.S. Department of Agriculture, Science and Education Administration, Agricultural Research Service, Weslaco, Texas 78596.

This study is a contribution from USDA, ARS, Soil and Water Conservation Research, Weslaco, Texas.

Authors thank Raul Tijerina, Jr., and the late J.O. Molina and his wife Gloria, for their support and cooperation during this study. The authors also acknowledge the help of M.A. Alaniz and G.V. Latigo, Weslaco, Texas, for their assistance in chemical analyses and sample collection.

Manuscript received November 24, 1980.
}

eaten by cattle, were generally available on the range during the study period. These 9 species made up at least $2 / 3$ of the cattle's diet (Everitt et al. 1981). Most of the information presented is based on these species; however, other short-lived species were temporarily available and were evaluated for their contribution to cattle's diet and nutritional requirements. Native grass species include Roemer threeawn (Aristida roemeriana), slender grama (Bouteloua repens), fringed signalgrass (Brachiaria ciliatissima), hooded windmillgrass (Chloris cucullata), red lovegrass (Eragrostis oxylepis), and fringeleaf paspalum (Paspalum setaceum). The introduced grass species were buffelgrass (Cenchrus ciliaris) and common bermudagrass (Cynodon dactylon); the browse species was pricklypear cactus (Opuntia lindheimeri).

Forage samples were collected monthly from pastures grazed by animals including total above ground herbage for grasses and upper pads for cactus. Composite samples from 15 or more plants of each species were washed with distilled water, dried at $65^{\circ} \mathrm{C}$, ground through a $1-\mathrm{mm}$ mesh screen in a plant mill, thoroughly mixed, and stored in sealed jars.

Samples were analyzed for nitrogen (N) by the Kjeldahl method (Peech et al. 1947). Percent $N$ values were multiplied by 6.25 , to convert them to percent crude protein (CP). Levels of $\mathrm{Ca}, \mathrm{Mg}, \mathrm{K}$, and $\mathrm{Na}$ were determined by atomic absorption spectrometry (Boettner and Grunder 1968). Lanthanum oxide was added to $\mathrm{Ca}$ and $\mathrm{Mg}$ samples to reduce interference. Phosphorus was determined by the rapid digestion method (Bolin and Stramberg 1944). Samples were analyzed in duplicate.

In vitro dry matter digestibility (IVDMD) percentages were determined using the two-stage technique developed by Tilley and Terry (1963). Periodically, cows grazing the forage sample area were slaughtered at a nearby slaughter house to obtain rumen inocula. Rumen materials were placed in an insulated container and taken to the USDA laboratory in Weslaco, Texas, within 10 to 15 minutes after cows were slaughtered. Triplicate samples of each forage species were inoculated with rumen fluids.

To compare forage crude protein with rumen crude protein, a random sample from within each individual rumen (fluids and solids) was taken, oven dried, and processed like forage samples in duplicate for $\mathbf{N}$ determination. A total of 48 rumen samples from 48 cows were sampled throughout the study period. Forty-eight samples spread out over the different seasons should indicate good forage representation in cattle diets.

Dry matter digestibility values were used to predict digestible energy (DE, $\mathrm{k} \mathrm{cal} / \mathrm{kg}$ ) using the regression equation developed by Rittenhouse et al. (1971) which is similar to that derived by Moir (1961). Its application to rangeland diets should indicate seasonal trends in DE. These values may be compared to cattle requirements (NRC 1976) by converting DE values to metabolizable energy (ME) using the following formula:

$$
\mathrm{DE}(\mathrm{M} \mathrm{cal} / \mathbf{k g}) \times 0.82=\mathrm{ME}(\mathrm{M} \mathrm{cal} / \mathbf{k g}) \text {. }
$$

This gives a DE level for lactating cows of $2.5 \mathrm{M} \mathrm{cal} / \mathrm{kg}$ or $2500 \mathrm{~K}$ $\mathrm{cal} / \mathrm{kg}$ and that of dry pregnant cows of $2.2 \mathrm{M} \mathrm{cal} / \mathrm{kg}$ or $2200 \mathrm{~K}$ cal $/ \mathrm{kg}$.

Data were analyzed for variance at the $5 \%$ probability level 
Table 1. Average seasonal and concentration of $P, N$, and $K$ chemical composition, digestible energy (DE), crude protein (CP), of plant species eaten by cattle on the Tijerina Ranch in south Texas.

\begin{tabular}{|c|c|c|c|c|c|c|c|c|c|c|c|c|c|c|c|}
\hline \multirow[b]{2}{*}{ Common name } & \multirow[b]{2}{*}{$\mathrm{S}^{2}$} & \multicolumn{4}{|c|}{$\mathrm{DE}^{\prime}(\mathrm{Kcal} / \mathrm{kg})$} & \multicolumn{5}{|c|}{$\mathrm{CP}(\%)$} & \multicolumn{5}{|c|}{$\mathrm{P}(\%)$} \\
\hline & & $S^{3}$ & $\mathbf{F}$ & W & $\bar{x}$ & $\mathrm{~s}$ & $\mathrm{~S}$ & $\mathrm{~F}$ & W & $X$ & $\mathbf{S}$ & s & $\mathrm{F}$ & $w$ & $\bar{x}-$ \\
\hline $\begin{array}{l}\text { Pricklypear } \\
\text { cactus }\end{array}$ & 3158 & 3166 & 2190 & 3098 & $2903 a^{4}$ & 5.7 & 6.3 & 5.5 & 5.8 & $5.8 \mathrm{~b}$ & 0.10 & 0.12 & 0.08 & 0.08 & $0.09 \mathrm{c}$ \\
\hline $\begin{array}{l}\text { Fringed } \\
\text { signalgrass }\end{array}$ & 1630 & 2080 & 1488 & 1590 & $1697 \mathrm{bcd}$ & 6.6 & 8.2 & 8.5 & 6.0 & $7.3 \mathrm{~b}$ & 0.08 & 0.18 & 0.15 & 0.10 & $0.12 b c$ \\
\hline Red lovegrass & 1810 & 1728 & 1380 & 1910 & 1707 bcd & 6.9 & 7.5 & 8.0 & 5.9 & $7.1 \mathrm{~b}$ & 0.10 & 0.15 & 0.16 & 0.12 & $0.13 b$ \\
\hline Ruemer threeawn & 1524 & 1396 & 1202 & 1218 & $1335 \mathrm{~d}$ & 6.9 & 6.5 & 7.3 & 5.9 & $6.7 \mathrm{~b}$ & 0.10 & 0.11 & 0.13 & 0.11 & $0.11 \mathrm{bc}$ \\
\hline Buffelgrass & 1684 & 1942 & 1672 & 1810 & 1777 bcd & 7.4 & 9.3 & 10.4 & 5.5 & $8.2 \mathrm{ab}$ & 0.13 & 0.19 & 0.23 & 0.23 & $0.19 \mathrm{~b}$ \\
\hline $\begin{array}{l}\text { Common } \\
\text { bermudagrass }\end{array}$ & 1858 & 1688 & 1492 & 1408 & $1611 \mathrm{~cd} 1$ & 12.5 & 11.0 & 13.9 & 8.0 & $11.4 \mathrm{a}$ & 0.34 & 0.32 & 0.34 & 0.15 & $0.29 \mathrm{a}$ \\
\hline $\begin{array}{l}\text { Hooded } \\
\text { wind millgrass }\end{array}$ & 1464 & 1622 & 1280 & 1432 & $1450 \mathrm{~cd}$ & 7.3 & 8.6 & 8.8 & 6.0 & $7.7 \mathrm{~b}$ & 0.11 & 0.16 & 0.18 & 0.10 & $0.13 b c$ \\
\hline Slender grama & 1512 & 1508 & 1344 & 1380 & $1436 \mathrm{~d}$ & 7.7 & 7.5 & 7.1 & 4.9 & $6.8 \mathrm{~b}$ & 0.13 & 0.13 & 0.16 & 0.09 & $0.12 b c$ \\
\hline $\begin{array}{l}\text { Fringeleaf } \\
\text { paspalum }\end{array}$ & 2316 & 2136 & 1830 & 2232 & $2129 \mathrm{~b}$ & 8.7 & 10.4 & 9.6 & 7.2 & $9.0 \mathrm{a}$ & 0.10 & 0.18 & 0.18 & 0.19 & $0.16 \mathrm{bc}$ \\
\hline \multirow[t]{2}{*}{$\bar{X}$} & $\begin{array}{c}1884 \\
\text { ab }\end{array}$ & $\begin{array}{c}1918 \\
a\end{array}$ & $\begin{array}{c}1542 \\
b\end{array}$ & $\begin{array}{c}1786 \\
a b\end{array}$ & 1783 & $\begin{array}{l}7.7 \\
\mathrm{a}\end{array}$ & $\begin{array}{l}8.4 \\
\mathrm{a}\end{array}$ & $\begin{array}{l}8.8 \\
a\end{array}$ & $\begin{array}{c}6.1 \\
b\end{array}$ & 7.8 & $\begin{array}{c}0.13 \\
b\end{array}$ & $\begin{array}{c}0.17 \\
\mathrm{a}\end{array}$ & $\begin{array}{c}0.18 \\
\mathbf{a}\end{array}$ & $\begin{array}{c}0.13 \\
b\end{array}$ & 0.15 \\
\hline & & \multicolumn{7}{|c|}{$\mathrm{Na}(\%)$} & \multicolumn{7}{|c|}{$\mathrm{K}(\%)$} \\
\hline \multicolumn{2}{|l|}{ Common name } & $\mathrm{S}$ & \multicolumn{2}{|l|}{$\mathrm{S}$} & $\mathrm{F}$ & W & \multicolumn{2}{|r|}{$\bar{X}$} & S & $\mathbf{S}$ & & $\mathbf{F}$ & $\mathbf{W}$ & \multicolumn{2}{|c|}{$\bar{X}$} \\
\hline \multirow{11}{*}{\multicolumn{2}{|c|}{$\begin{array}{l}\text { Pricklypear cactus } \\
\text { Fringed signalgrass } \\
\text { Red lovegrass } \\
\text { Romer threeawn } \\
\text { Buffelgrass } \\
\text { Common bermudagrass } \\
\text { Hooded windmillgrass } \\
\text { Slender grama } \\
\text { Fringeleaf paspalum } \\
\qquad \frac{X}{}\end{array}$}} & 0.02 & \multicolumn{2}{|l|}{0.01} & 0.01 & 0.01 & \multicolumn{2}{|r|}{$0.01 \mathrm{~b}$} & 3.40 & 3.06 & & 3.23 & 3.30 & \multicolumn{2}{|r|}{$3.25 \mathrm{a}$} \\
\hline & & 0.03 & \multicolumn{2}{|l|}{0.04} & 0.03 & 0.02 & \multicolumn{2}{|r|}{$0.03 \mathrm{~b}$} & 1.22 & 1.75 & & 1.70 & 1.01 & \multicolumn{2}{|r|}{$1.42 \mathrm{abcd}$} \\
\hline & & 0.03 & \multicolumn{2}{|l|}{0.04} & 0.05 & 0.04 & \multicolumn{2}{|r|}{$0.04 \mathrm{~b}$} & 0.82 & 0.99 & & 1.12 & 0.77 & \multicolumn{2}{|r|}{$0.92 \mathrm{~cd}$} \\
\hline & & 0.04 & \multicolumn{2}{|l|}{0.05} & 0.04 & 0.03 & \multicolumn{2}{|r|}{$0.04 \mathrm{~b}$} & 0.49 & 0.62 & & 0.72 & 0.47 & \multicolumn{2}{|r|}{$0.57 \mathrm{~d}$} \\
\hline & & 0.03 & \multicolumn{2}{|l|}{0.04} & 0.06 & 0.03 & \multicolumn{2}{|r|}{$0.04 \mathrm{~b}$} & 1.20 & 2.80 & & 3.29 & 1.24 & \multicolumn{2}{|r|}{$2.15 \mathrm{ab}$} \\
\hline & & 0.02 & \multicolumn{2}{|l|}{0.05} & 0.06 & 0.02 & & $0.03 \mathrm{~b}$ & 1.42 & 1.14 & & 2.00 & 1.24 & & $1.58 \mathrm{abcd}$ \\
\hline & & 0.06 & 0.09 & & 0.11 & 0.06 & & $0.08 \mathrm{a}$ & 1.18 & 1.54 & & 1.68 & 0.95 & & $1.33 \mathrm{bcd}$ \\
\hline & & 0.02 & 0.02 & & 0.03 & 0.02 & & $0.02 \mathrm{~b}$ & 0.59 & 0.80 & & 0.90 & 0.50 & & $0.69 \mathrm{~d}$ \\
\hline & & 0.08 & 0.11 & & 0.09 & 0.06 & & $0.08 \mathrm{a}$ & 1.49 & 2.27 & & 2.56 & 1.59 & & $1.97 \mathrm{abc}$ \\
\hline & & 0.04 & 0.06 & & 0.06 & 0.04 & & 0.05 & 1.27 & 1.74 & & 1.96 & 1.21 & & 1.47 \\
\hline & & $b$ & a & & a & b & & & $\mathbf{b}$ & $\mathbf{a}$ & & $\mathbf{a}$ & $\mathbf{b}$ & & \\
\hline
\end{tabular}

IDigestible energy is based on IVDMD.

2Letters represent seasons in following order: $S=$ spring, $S=$ summer, $F=$ fall, $W=$ winter.

${ }^{3}$ All summer averages are for 3 years $(1975,1976,1977)$; all other seasonal averages are for 2 years (1976 and 1977).

4 Mean row or column values followed by the same letter do not differ significantly at the $5 \%$ probability level, according to Duncan's multiple range test.

(Cochran and Cox 1956). Sampling dates were used as replications. Duncan's multiple range test was used to test differences among means.

\section{Results and Discussion}

The chemical composition, CP, and DE of clipped range forages are summarized by seasons and by species in Table 1 and Figure 1.

\section{Digestible Energy (DE) (Based on IVDMD)}

Overall means of all species indicated that DE levels in summer were significantly higher than those in the fall; however, spring and winter DE levels did not differ significantly from either summer or fall. Pricklypear cactus had significantly higher DE levels than all other species during all seasons. Among the grass species, fringeleaf paspalum had higher DE levels than most other species. Generally, most grasses had higher DE levels in spring and summer and lower levels in fall and winter. Slender grama and Roemer threeawn had the lowest DE levels.

The seasonal average DE levels $(1783 \mathrm{~K} \mathrm{cal} / \mathrm{kg})$ were lower than the 2200 and $2500 \mathrm{~K} \mathrm{cal} / \mathrm{kg}$ required to meet the needs of dry and lactating cows, respectively (NRC 1976). Pricklypear cactus was the only species whose seasonal average met $D E$ requirements for both dry and lactating cows. Similar observations have been reported for Plains pricklypear (Shoop et al. 1977). However, pricklypear cactus is high in soluble ash (20\%) and if its DE level is expressed as in vitro digestible organic matter, DE is considerably lower (Everitt and Gonzalez 1981). Fringeleaf paspalum was the only grass species where DE level was sufficient to meet dry cow requirements in summer and winter. All other grasses were defi- cient for all seasons. Although the DE values for most grass species were low, these data agreed with those reported in other studies (Woolfolk et al. 1975, Conrad and Holt 1979, McAtee et al. 1979). Seasonally, some foods that are high in DE become available and make up for some of these deficiencies. For example, mesquite (Prosopis glandulosa) beans, whose DE levels average $2460 \mathrm{cal} / \mathrm{kg}$, are available in late summer and early fall. Also, some forbs and sedges are heavily grazed by cattle during the summer and fall (Everitt et al. 1981); they may contribute substantial levels of DE.

\section{Crude Protein (CP)}

Mean CP percentages of all species were significantly lower in winter than during the other 3 seasons. Among species, common bermudagrass and fringeleaf paspalum had significantly higher mean CP levels than all other species, except buffelgrass. Generally, pricklypear had lower levels of CP throughout the year than did most grasses.

The National Research Council (NRC) (1976) recommended 9.2 and $5.9 \% \mathrm{CP}$ for lactating and dry cows, respectively. Of the grasses studied, only common bermudagrass had a CP content that met lactating cow requirements all seasons, except, winter, when CP levels met only the requirements of dry cows. Both buffelgrass and fringeleaf paspalum met cattle requirements in summer and fall but they were deficient in winter and marginal in spring. Based on the season mean CP content for all plants analyzed, CP levels readily met requirement for dry cows, but not for lactating cows. Protein probably should be supplemented in winter and early spring. 

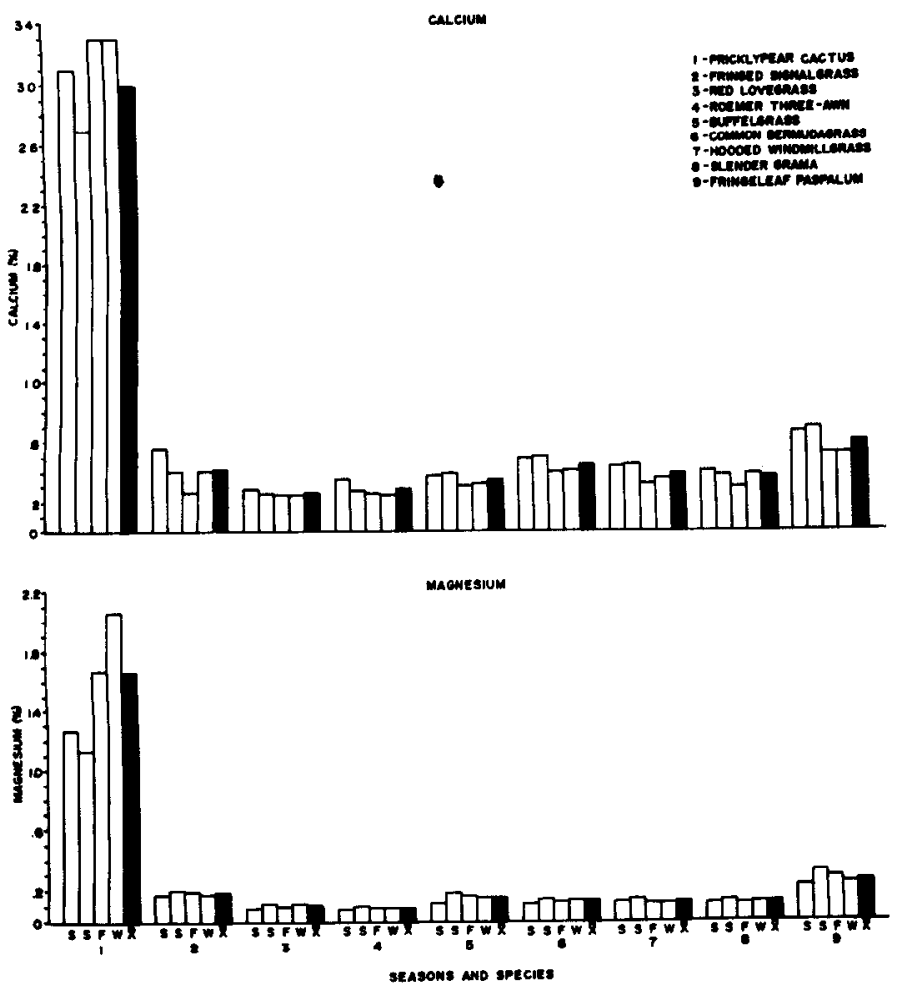

Fig. 1. Percent calcium and magnesium contents of 8 grasses and 1 browse species used by cattle in the Tijerina Ranch in south Texas. Letters in bars are in following order: $S=$ spring, $S=$ summer, $F=$ fall, $W=$ winter and $X=$ mean. All summer averages are for 3 years: 1975, 1976, 1977; other seasonal averages are for 2 years: 1976 and 1977.

\section{Phosphorus (P)}

Phosphorus content of all herbage studied was generally low. Means of all species were significantly higher in summer and fall than in winter and spring. Among the species studied, pricklypear cactus had the lowest and common bermudagrass had the highest $P$ levels. Common bermudagrass $P$ concentration remained high during all seasons, except winter. Buffelgrass had the second highest $\mathbf{P}$ level among the species analyzed. Seasonal means $\mathbf{P}$ levels of all species for all seasons, except fall, were below the levels of 0.18 and 0.39 considered adequate for dry and lactating cows, respectively (NRC, 1976). Since P deficiencies are extremely critical, especially when $\mathrm{Ca}$ concentrations are high (Hill and Guss 1976), $\mathrm{P}$ probably should be supplemented free choice throughout the year.

\section{Sodium (Na) and Potassium (K)}

Mean levels of $\mathrm{Na}$ and $\mathrm{K}$ followed the same seasonal trendsignificantly higher in summer and fall than in the spring and winter. Fringeleaf paspalum and hooded windmillgrass had significantly higher mean $\mathrm{Na}$ levels than all other species. Mean $\mathrm{Na}$ levels in forage for all species were below the $0.06 \%$ level considered adequate for beef cattle (NRC 1976). However, Na deficiencies rarely occur because it is common practice to supply salt blocks. Among the forage species analyzed, Roemer threeawn had the lowest $\mathrm{K}$ levels, while pricklypear cactus had the highest. The $\mathrm{K}$ level of all forage species were well above the $(0.6$ to $0.8 \%) \mathrm{min}$ imum requirement range (NRC 1976).

\section{Calcium (Ca) and Magnesium (Mg)}

Mean $\mathrm{Ca}$ and $\mathrm{Mg}$ levels did not differ significantly among seasons; however, among species, pricklypear cactus contained significantly higher levels of both minerals. The seasonal $\mathrm{Ca}$ and $\mathrm{Mg}$ contents of each species are presented in Figure 1 . All plants had $\mathrm{Ca}$ levels that exceeded beef cattle requirements $(0.18$ to $0.44 \%$ ) (NRC 1976).

The required $\mathrm{Mg}$ level in ruminant diets depends on many factors. Although beef cattle $\mathrm{Mg}$ requirements are low (0.04 to $0.18 \%$ ) (NRC 1976), Mg should not be deficient if $\mathrm{K}$ is present in excess because hypomagnesemic tetany could occur. According to Hill and Guss (1976), a forage diet with less than 20\% CP and 3.0\% $\mathrm{K}$, should contain $0.20 \% \mathrm{Mg}$. All forage grasses met this requirement, thus, no tetany problem should occur. Only pricklypear cactus had excessively high $\mathrm{Mg}(1.7 \%)$ and $\mathrm{K}(3.3 \%)$ levels. However, the $\mathrm{Mg}$ and $\mathrm{K}$ levels of all grass species were within the accepted range. Most of the forage species, except pricklypear cactus, had Ca:P ratios near $2: 1$, which is considered ideal for ruminants according to Maynard and Loosli (1969).

\section{Livestock Drinking Water}

The chemical composition of cattle drinking water is often ignored. On this range site, well water had about $1350 \mathrm{ppm}$ total soluble salts, which included $5.1,2.9,25.6$, and $3.6 \%$ of $\mathrm{Ca}, \mathrm{Mg}$, $\mathrm{Na}$, and $\mathrm{K}$, respectively. Therefore, drinking water might supply elements that are deficient in range forage.

\section{Rumen Crude Protein (CP) vs Herbage Crude Protein (CP)}

Rumen CP exceeded herbage CP (by about $2 \%$ ) in all seasons (Fig. 2); however, rumen CP followed the same general seasonal pattern as herbage CP. Similar observations were reported by and Shumway (1966). The main reason for higher rumen $C P$ content in summer was probably due to selective animal grazing (Cook and Harris 1968, Nelson et al. 1970, Wallace et al. 1972). Cable and Shumway (1966) reported that in some grasses the young green material is 1.7 to 2.5 times higher in crude protein than the whole plant or older plant parts. Similar results have been reported in California (Van Dyne and Heady 1965).

Rumen CP content was high enough to meet requirements for both dry and lactating cows. However, mean herbage CP levels only met requirements of dry cows and was always deficient for lactating cows.

The fact that most samples analyzed were from whole plants might tend to underestimate the value of some nutrients, since animals are very selective and usually eat the greener and younger plant growth when available. Because the vegetation of the study area is typical of much of the South Texas Plains, these data should provide an index to the nutritional quality of forage selected by cattle in south Texas.

\section{Summary and Recommendations}

The nutritive value of major plant species of native rangeland grazed by cattle in south Texas changes seasonally. Data for 2.5 years, showed that most nutrients were more available in summer and fall than in winter and spring. Digestible energy, $C P$, and $P$ levels were deficient, especially in winter and early spring, for lactating cows, but were near marginal for dry cows. All other elements were present in amounts adequate to meet all cattle

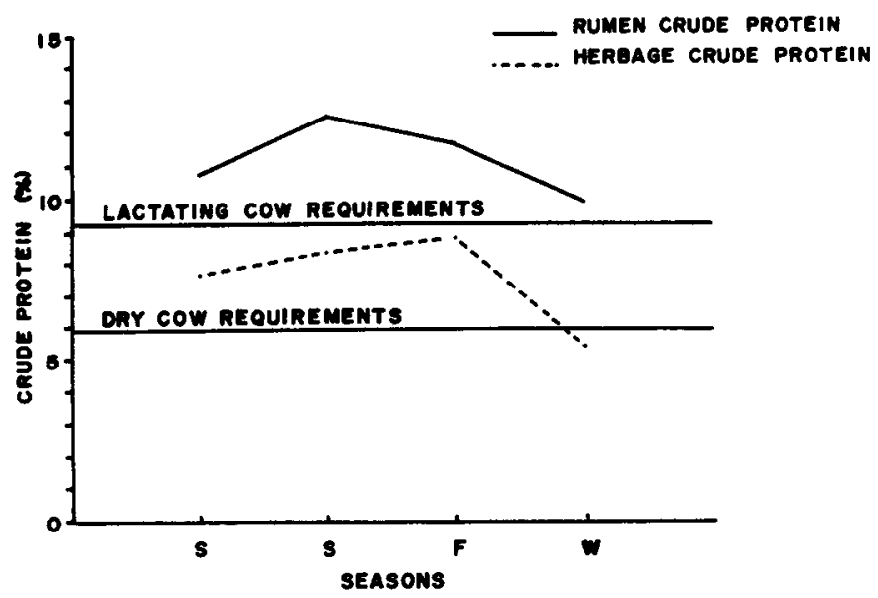

Fig. 2. Rumen crude protein levels as compared with herbage crude protein levels during spring, summer, fall, and winter. 
requirements. Sodium levels were low in most species, but $\mathrm{Na}$ intake is probably adequate because salt blocks are usually provided and $\mathrm{Na}$ levels in cattle drinking water are high.

A comparison of herbage versus rumen $C P$ levels showed that cattle selected a diet higher in CP than that represented by analyses of whole plant hand-clipped samples. The higher rumen CP content was probably due mostly to selective grazing or green parts of grasses, rather than to their eating the whole plant, and to the grazing of high protein forbs when they became available.

Most foods used by cattle are perennial grasses such as red lovegrass, Roemer's threeawn, and hooded windmillgrass. These species should be the focal point to determine and evaluate current cattle stocking rates. Other grasses, like fringeleaf paspalum and buffelgrass, provide a high quality food source when they are available. Although pricklypear cactus had relatively low levels of $C P$ and $P$, its relatively high $D E$ level makes it an important contributor to cattle's diets. This study suggests that protein should be supplemented to lactating cows in winter and early spring, whereas $\mathbf{P}$ probably should be supplemented all year.

\section{Literature Cited}

Boettner, E.A., and F.I. Grunder. 1968. Water analysis by atomic absorption and flame emission spectroscopy. In: Trace inorganics in water (R.A. Baker, ed.). Adv. in Chem. Ser., Amer. Chem. Soc. 73:1-386.

Bolin, O.W., and O.E. Stramberg. 1944. Rapid digestion method for determination of phosphorus. Indus. and Engin. Chem. Analyt. Ed. 16:345-346.

Cable, D.R., and R.P. Shumway. 1966. Crude protein in rumen contents and in forage. J. Range Manage. 19:124-128.

Cochran, W.G., and G.M. Cox. 1956. Experimental design. John Wiley and Sons, Inc., New York. 454 p.

Conrad, B.E., and E.C. Holt. 1979. Evaluation of bermudagrass hybrids for forage quality. Texas A\&M Univ., Tex. Agr. Exp. Sta., College Station. PR-3547.

Cook, C.W., and L.E. Harris. 1968. Nutritive value of seasonal ranges. Utah State Univ. Agr. Exp. Sta. Logan. Bull. 472.55 p.

Davis, R.B. 1952. The use of rumen contents data in a study of deer-cattle competition and "animal equivalence." Trans. N. Amer. Wildl. Conf. 17:448-458.

Everitt, J.H., and C.L. Gonzalez. 1981. Seasonal nutrient content in food plants of white-tailed deer on the South Texas Plains. J. Range Manage. 34:506-510.
Everitt, J.H., C.L. Gonzalez, G. Scott, and B.I. Dahl. 1981. Seasonal food preferences of cattle on native range in the South Texas Plains. J. Range Manage. 34:384-388.

Gould, F.W. 1975. Texas plants-A checklist and ecological summary. Texas Agr. Exp. Sta., Texas A\&M Univ., College Station. MP-585. 121 p.

Hill, R.R., Jr., and S.B. Guss. 1976. Genetic variability for mineral concentration in plants related to mineral requirements of cattle. Crop. Sci. 16:680-685.

Maynard, L.A., and J.K. Loosli. 1969. Animal nutrition. McGraw-Hill, New York. 613 p.

Moir, R.J. 1961. A note on the relationship between digestible dry matter and digestible energy content of ruminant diets. Australian J. Exp. Agr. and Anim. Husb. 1:24.

McAtee, J.W., C.J. Scifres, and D.F. Drawe. 1979. Digestible energy and protein content of gulf cordgrass following buming or shredding. $J$. Range Manage. 32:376-378.

Nelson, A.B., C.H. Herbel, and H.M. Jackson. 1970. Chemical composition of forage species grazed by cattle on an arid New Mexico Range. $\mathbf{N}$. Mexico State Univ. Agr. Exp. Sta., Las Cruces. Bull. 561.

N.R.C. 1976. Nutrient requirements of domestic animals, No. 4. Nutrient requirements of beef cattle. Fifth revised edition, Nat. Res. Counc., Washington, D.C.

Peech, M.L., A. Dean, and J.F. Reed. 1947. Methods of soil and analysis for fertility investigations. USDA Circ. 754:1-25.

Rittenhouse, L.R., C.L. Streeter, and D.C. Clanton. 1971. Estimating digestible energy from digestible dry and organic matter in diets of grazing cattle. J. Range Manage. 24:73-75.

Shumway, R., Phil Hubbert, Jr., W.T. Hayer, III, D.R. Cable, and W.H. Hale 1963. A qualitative determination of the diet of grazing steers under desert grassland conditions. West. Sect. Amer. Soc. Anim. Sci. Proc. 14:38(1-6).

Shoop, M.C., E.S. Alford, and H.F. Mayland. 1977. Plains pricklypear is a good forage for cattle. J. Range Manage. 30:12-17.

Tilley, J.M.A., and R.A. Terry. 1963. A two-stage technique for the in vitro digestion of forage crops. J. British Grassland Soc. 18:104-1II.

Van Dyne, G.M., and H.F. Heady. 1965. Botanical compostion of sheep and cattle diets on a mature annual range. Hilgardia. 36:465-492.

Wallace, J.D., J.C. Free, and A.H. Denham. 1972. Seasonal changes in herbage and cattle diets on sandhill grassland. J. Range Manage. 25:100104.

Woolfolk, J.S., Ed. F. Smith, R.R. Shcalles, B.E. Brent, L.H. Harbers, and C.E. Owensby. 1975. Effects of nitrogen fertilization and late spring burning of bluestem range on diet and performance of steers. J. Range Manage. 28: 190-193. 